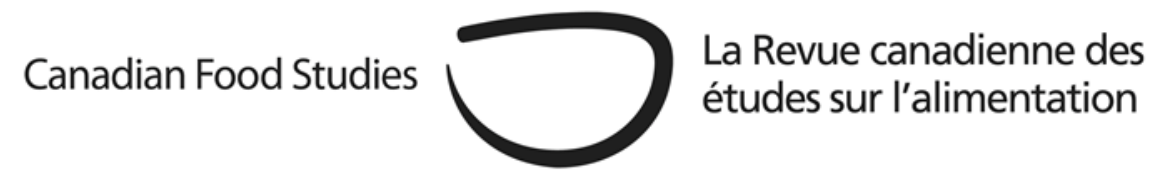

Original Research Article

\title{
Addressing the call: A review of food justice courses in Canada and the USA
}

Meryn Corkery*, Will Valley, Joyce Liao, and Colin Dring

University of British Columbia

\section{Abstract}

To address inequality's root causes both within and beyond the food chain, food justice scholars have called for explicit integration of trauma/inequity, land, labour, exchange, and governance into post-secondary education food studies and related fields. This paper explores how instructors of food justice courses (identified by key-word internet search) in Canada and the United States are designing their courses. We collected course syllabi from fifteen institutions to determine key themes related to course content based on weekly topics and readings, resulting in the identification of 16 thematic content areas. We identified seven thematic areas related to course goals $(n=49)$ and eight thematic areas related to learning outcomes $(n=123)$. To clearly distinguish between themes represented in the syllabi, we embedded course goals and learning outcomes into the Understanding by Design instructional design framework, which demonstrates how course goals can be separated into the categories of transfer and meaning, and learning outcomes into declarative and procedural knowledge. We examine content areas in relation to food justice scholarship, focusing on what is present, underrepresented, and absent. In consideration of the Understanding by Design framework, we discuss the need for established goals within which to situate food justice courses, challenges of course scope, value of scaffolding goals and outcomes across programs, and future directions for aligning potential indicators of understanding and identifying effective learning activities. The intended outcome of the paper is to provide current and prospective instructors with greater clarity on how food 
justice is being taught in order to increase our collective effectiveness in developing student capacities in the field.

Keywords: Food justice; pedagogy; critical pedagogy; food systems pedagogy; sustainable food systems

\section{Introduction}

Over the last two decades, there has been an increased interest in the intersections between food systems, ecological sustainability, and social justice. Activists and scholars have been working to understand social inequities related to race, class, gender, sexual orientation, and colonization, and recognize how they are reproduced, resisted, and contested within food systems (Glennie \& Alkon, 2018). Often referred to as food justice, the concept, process, and practice of food justice has been mobilized as a key aspirational rallying point for social movements, non-profit organizations and networks, and scholar-activists to transform the food system (Alkon \& Agyeman, 2011; Allen, 2008; Gottlieb \& Joshi, 2010; Holt-Giménez, 2016; Herman et al., 2018). The growing influence of food justice projects and scholarship has resulted in calls for postsecondary institutions to attend to both their complicity in, and responsibility to, addressing social inequities through curriculum, pedagogy, and community engagement (Anderson et al., 2019), which has resulted in an uptake in food justice themed courses and content in food-related programs. In this paper, we aim to examine what postsecondary instructors are offering in response to the growth in scholarly interest in food justice. The objectives of the paper are: (1) To explore how instructors articulate content areas, course goals, and learning outcomes for food justice courses offered in postsecondary education in Canada and the United States; and (2) To situate course goals and learning outcomes within a common instructional design framework (Understanding by Design) to support curriculum development in food justice courses (Wiggins $\&$ McTighe, 2005). The intended outcome of the paper is to provide current and prospective instructors with greater clarity on how food justice is being taught in order to increase our collective effectiveness in developing student capacities in the field. In the following sections, we describe how we conceptualize food justice relative to common scholarly definitions, broad trends and orientations in the field, and scholarship of teaching and learning in food-related fields that incorporate food justice content and topics. We then outline the core stages of the Understanding by Design (UbD) (Wiggins \& McTighe, 2005) instructional design framework to position the results of our analysis of the food justice course syllabi relative to Stage 1 of the UbD framework. 


\section{Food justice: Conceptualization and orientations}

There are numerous interpretations of what food justice means. One of the most cited definitions comes from Gottlieb \& Joshi (2010), "we characterize food justice as ensuring that the benefits and risks of where, what, and how food is grown and produced, transported and distributed, and accessed and eaten are shared fairly" (p. 6). Drawing from environmental justice literature, we find it helpful to supplement the distributional justice described in Gottlieb \& Joshi's (2010) definition with two additional dimensions of justice: procedural and epistemic. The former orients attention towards representation and decision-making power, and the latter refers to whose knowledge is recognized, valued, prioritized, dismissed, or disappeared (Gibb \& Wittman, 2013). The concept of justice employed in food systems positions "the need to address inequalities' root causes at the forefront of a transformative food agenda... it is paramount to acknowledge [food justice's] place-based character, relationality and inherently political character" (Moragues-Faus, 2018, p. 1097). Similar to Glennie and Alkon (2018), we adopt Hislop's (2014) broad definition of food justice as "the struggle against racism, exploitation, and oppression taking place within the food system that addresses inequality's root causes both within and beyond the food chain" (p. 24).

In their evidence-based review of articles and books $(n=200)$ related to food justice in the United States, Glennie and Alkon (2018) found that food justice research can be organized around three central themes: social movement activism, development of alternative food practices, and analyses of food system inequalities. A rich body of scholarly work has documented the relationships between food, structural inequality, and race (Slocum, 2007; Myers \& Painter, 2017; Garth \& Reese, 2020), income (Loopstra \& Tarasuk, 2013), gender (Allen \& Sachs, 2012), labour (Sbicca, 2015), and colonialism (Morrison, 2011; Bradley \& Herrera, 2016; Daigle, 2019). While this research is vital, the use of food as an organizing strategy and means to address social change is not new. It is important to recognize practices arising from other social, economic, and civil rights projects as comprising food justice. This includes efforts in the United States such as the Black Panthers Breakfast Program, Food Not Bombs, the Delano Grape Strike (Holt-Giménez \& Wang, 2011), and Freedom Farmers (White, 2018), and in Canada, the National Farmers Union organizing boycotts and demonstrations (Desmarais \& Wittman, 2014) and the efforts of the Working Group on Indigenous Food Sovereignty (Morrison, 2011). Whether or not these initiatives identify explicitly as "food justice" efforts, food is regularly employed as a tool for addressing injustice beyond the confines of food system transformation (Mares \& Peña, 2011).

Food justice proponents argue that food justice practice coalesces on the realms of trauma/inequity, land, labour, exchange (Cadieux \& Slocum, 2015), and governance (Horst, 2017). In terms of the role of education in food justice, Glennie and Alkon's (2018) review points to two areas of scholarship: analyses of social or educational programs $(n=7)$ and food justice movements contributing to environmental education or social work $(n=3)$. 
While the review does not indicate who is implementing these educational programs, the presence of research examining educational initiatives is important. As Sumner (2016) writes, "faced with a suite of environmental, social, cultural, and economic problems associated with the global corporate food system, it is time to ask: What is the role of education? Does it merely promote adaptation to this unsustainable system, or can it encourage the kind of learning experiences that will contribute to much-needed change" (p. xxvi).

\section{Education and food system transformation}

Broadly, education is considered a key element in the agenda for food system transformation, with a rich tradition of use in social movements, non-profit, and peasant organizations, and by radical educators/scholar-activists (Anderson et al., 2019; Meek et al., 2019; Holt-Gimenez \& Wang, 2011). As Hislop's (2014) survey of United States non-profit food justice organizations demonstrated, $57 \%$ of organizations surveyed $(n=105)$ stated food systems education as a key goal. As a critical component to many non-profit food justice organizations, a theory of change is posited that to change the system, peoples' minds must also change. The Sustainable Agriculture Education Association (SAEA), an educational non-profit society focused on the development and exchange of teaching and learning practices in postsecondary education, explicitly centres the active confrontation of racism, patriarchy, and white supremacy in food systems teaching and learning through its equity statement (SAEA, 2019). Social justice concepts and issues are also prominent in the scholarship of teaching and learning in fields of study associated with agriculture and food systems, appearing in specializations labelled food studies, critical food pedagogy, critical education for food systems transformation, critical food systems education, and sustainable food systems education. Below, we highlight the ways in which each specialization connects to key themes related to food justice to demonstrate the range of academic programs in postsecondary education that may offer food justice courses.

Food studies are often associated with social science programs and "focus on cultural, historical, or other academic perspectives on food" (Hartle et al., 2017, p. 40). Koç et al. (2012) define food studies as a field that "focuses on the web of relations, processes, structures, and institutional arrangements that cover human interactions with nature and other humans involving the production, distribution, preparation, consumption, and disposal of food" (p. xiv). Within the field, there is a significant focus on addressing social and political challenges (Berg et al., 2003; Cargill, 2005; Hamada et al., 2015), adopting a systemic approach to analysis, and orientations towards social movements to transform the food system (Anderson et al., 2016; Levkoe et al., 2020). Recent scholarship of teaching and learning in food studies has called for greater integration of an intersectional lens (Williams-Forson \& Wilkerson, 2011), including specific attention to race, class, gender, disability, and interspecies relations and animal oppression (Probyn-Rapsey et al., 2016; Sachs \& Patel-Campillo, 2014; Julier, 2019; Lloro-Bidart, 2019). 
Critical food pedagogy scholarship describes shifting and expansive approaches to teaching and learning that include a combination of food-related content with experiential learning processes, diverse ways of knowing about food, and social, environmental, and economic inequalities resulting from power relations (Flowers \& Swan, 2012, 2015). Critical food pedagogy explicitly examines the shifting power relations in modern food systems and food justice. A critical pedagogy approach attends to food education as a political process, interrogates structures leading to inequality (Butterwick, 2005), and explicitly links power issues as integral to pedagogical scholarship and practice (Finger, 2005). In Sumner's (2015) work, she describes a graduate-level course with the goal of helping students "gain a basic understanding of the critical pedagogy of food, while the objectives included cultivating an understanding of the interface between the field of adult education and food; appreciating the importance of this interface within the global and local context; gaining familiarity with issues associated with food; and raising awareness of the importance of food in any pedagogical endeavour" (p. 206).

Critical education for food systems transformation and critical food systems education draws on critical pedagogy, critical race, feminist, queer, and social movement theory (Anderson et al., 2019; Meek et al., 2019; Meek \& Tarlau, 2015, 2016) to cultivate learner consciousness and capacity for reason, action, and work towards social justice. The scholarship of both specializations is closely associated with educational initiatives embedded in grassroots and social movements related to food sovereignty, food justice, and agroecology. Their shared educational task is "to leverage the broader educational system and innovative pedagogical techniques so that students and educators can utilize food system knowledge and agroecological practices to systematically dismantle the structural and ideological elements of the corporate food regime and develop transgressive subjectivities" (Meek et al., 2019, p. 612).

Sustainable food systems education (SFSE) programs are often associated with natural science programs, characterized by an emphasis on systems thinking, multi/inter/transdisciplinarity, and community engagement through collective action projects (Jordan et al., 2014; Valley et al., 2018; Ebel et al., n.d., in press). Proponents of SFSE argue that postsecondary institutions are tasked with supporting the development of professionals that have "new capacities for collective intelligence and integrated action, requiring, in turn, new kinds of knowledge, skills and dispositions" (Valley et al., 2018, p. 2). Central to efforts to transform food systems in SFSE scholarship is an emphasis on making explicit the implicit values, attitudes, and aspirations of curriculum and formal degree programs (Galt et al., 2012; Anderson, 2013; Valley et al., 2018). However, Valley et al. (2020) found that $81 \%$ of SFSE degree programs $(n=108)$ across Canada and the United States did not include any explicit mention of equity terms and concepts in public-facing degree program materials. SFSE programs may or may not have an explicit orientation towards developing student capacity to dismantle systemic oppression in their professional or personal practice. However, recent work in the SFSE literature is challenging this deficit and advocating for an increased orientation towards food justice related issues and integration of curriculum and pedagogical processes to develop equity competencies (Valley et al., 2020). 


\section{Understanding by design}

Instructional design frameworks are commonly used as a starting point for guiding the development of postsecondary courses. They can also be used as an analytical tool to understand the internal coherence of an existing course, or collection of courses, by distinguishing between scope, purpose, goals, and outcomes, and the external correspondence of a course to a field of study or broader educational standards. We selected the Understanding by Design (UbD) framework (Wiggins \& McTighe, 2005) as it is regularly employed by educational professionals in course design and in educational scholarship (as of July 2020, over 10,000 citations in Google Scholar). More specifically, it has been used in peer-reviewed scholarship related to food systems (Chornyak, 2015), food security (Boger et al., 2019), sustainability (Brundiers \& Wiek, 2017; Santone et al., 2014), and social justice (Loya, 2020) courses. UbD offers a useful heuristic irrespective of whether the instructor employed the instructional design approach at the outset.

$\mathrm{UbD}$ is used to "focus teaching on the development and deepening of student understanding and transfer of learning" (Wiggins \& McTighe, 2011, p. 3). UbD is described as a backward design process and comprises three stages: Desired Results, Evidence, and Learning Plan. Wiggins and McTighe (2005) argue that beginning with goals and specific results of teaching helps overcome recurring problems in instructional design: directionless coverage of content and isolated learning activities.

Stage 1 (Desired Results) begins with identifying established goals from external design standards, such as mission-related goals, program-level learning objectives, or graduate attributes articulated in a field's scholarship of teaching and learning. These long-term priorities are crucial for maintaining perspective on what to include, cut out, emphasize, and minimize when teaching. Next, course goals are developed to identify enduring understandings, which Wiggins and McTighe (2011) separate into transfer and meaning. Transfer refers to being able to independently take what has been learned (i.e., understandings, knowledge, and skills) and apply it effectively in another context. Meaning refers to students ability to make inferences and grasp connections, which in the UbD template for Stage 1 is further separated into "Understandings": "an important generalization, a new insight, a useful realization that makes sense out of prior experience, or learning that was either fragmented or puzzling" (Wiggins \& McTighe, 2011, p. 14); and "Essential Questions", that push the learner to "look for familiar patterns, connect ideas, and consider useful strategies when faced with novel challenges" (Wiggins \& McTighe, 2011, p. 15). The final section of Stage 1 is the acquisition of declarative and procedural knowledge. This section relates to identifying specific, measurable, short-term learning outcomes that articulate basic facts and concepts students should know as well as discrete skills and processes students should be able to use by the end of the course (Wiggins \& McTighe, 2011).

Stages 2 (Evidence) focuses on determining indicators of learning related to knowledge, skills and understandings articulated in Stage 1. Evidence of learning is demonstrated by summative assessment strategies which provide students with opportunities to "flexibly and 
intelligently use what they know, in a new complex situation where higher-order thinking in the use of content is required" (Wiggins \& McTighe, 2011, p. 24). Stage 3 (Learning Plan) is where an instructor determines the most appropriate activities needed to develop student capacity to acquire learning outcomes and course goals. In this paper, due to our choice to use course syllabi as our data source and considerations of manuscript length, we limit our results and discussion to Stage 1 of the UbD framework; however, it is important to be familiar with the composition and purposes of Stage 2 and 3 to recognize the connections to content articulated in the first stage of the template (i.e., Table 5 in results).

In the remainder of the paper, we present our methods, results, and discussion based on our research questions:

1. What content areas are being included in our sample of food justice courses in Canada and the United States?

2. What are common course goals and learning outcomes in food justice courses? How do course goals and learning outcomes from the sample of food justice syllabi fit within Stage 1 of the UbD framework?

\section{Methodology}

To identify how instructors are teaching food justice in a postsecondary context, we conducted an environmental scan for food justice course syllabi in Canada and the United States. An environmental scan, often used in the health sciences and public health field, allows researchers to collect and collate information from many sources using a flexible and responsive framework (Graham et al., 2008; Kipp et al., 2019; Rowel et al., 2005). Once we had compiled our sample of syllabi, we conducted a qualitative analysis based on the steps outlined by Creswell (2014): organize and prepare data for analysis, read through all data, code data (descriptive and thematic), interrelate themes/descriptions, and interpret the meaning of themes/descriptions. Course syllabi are a standard component of postsecondary teaching, however, content within syllabi varies. Our sample of syllabi contained a large volume of information, such as course policies, logistical information, assignment weighting and descriptions, and learning activities. For comparability purposes, our analysis focused on elements of the syllabi that were consistently present across the sample, which were course content areas, course goals, and learning outcomes.

\section{Identifying courses}

A Google search completed during March 2019 using Boolean operators and key terms "food" AND "justice"; "food justice"; "food" AND "social justice"; "food justice course syllabus", "food justice course" identified twenty-one postsecondary courses related to food and 
social justice and/or food justice in Canada and the United States. Of these courses, six were excluded: four syllabi were not available after contacting the course instructor, one institution indicated that the syllabi could not be shared publicly, and one publicly available syllabus did not contain enough information to analyze, as it lacked course content areas and learning outcomes. While we acknowledge that this method for identifying courses is likely not comprehensive of all existing food justice courses in Canada and the United States, we feel that the sample is large enough to gain significant and meaningful information to answer our research questions. Furthermore, we pursue a range of perspectives and efforts, not to make general claims of representativeness from this study.

Our final sample included fifteen syllabi for analysis, ranging from 2008 to 2019. Ten syllabi were publicly available and five were acquired upon contacting course instructors and receiving permission to be included in our study. Courses were embedded across a range of academic disciplines (Table 1).

Table 1: Academic domains and disciplines associated with food justice courses in sample

\begin{tabular}{|l|c|l|}
\hline Domain & $\begin{array}{l}\text { Number of } \\
\text { Syllabi }\end{array}$ & Specific Disciplines \\
\hline Social Sciences & 7 & $\begin{array}{l}\text { Sociology (2); Philosophy; Anthropology; Africana Studies \& American } \\
\text { Studies (cross listed); Communication; Health Education }\end{array}$ \\
\hline $\begin{array}{l}\text { Public Administration } \\
\text { and Policy }\end{array}$ & 3 & $\begin{array}{l}\text { Public Administration; Urban and Environmental Policy; Planning and Policy } \\
\text { \& Nutrition Science and Policy (cross listed) }\end{array}$ \\
\hline Natural Sciences & 3 & Agriculture and Food Systems; Environmental Science (2) \\
\hline Other & 2 & Sustainable Local Food Certificate; Interdepartmental \\
\hline
\end{tabular}

Our sample contained ten courses offered at public institutions and five offered at private institutions. Courses were mostly at the undergraduate-level $(n=10)$, with a smaller proportion of graduate courses $(n=2)$, and two courses that were cross listed as undergraduate and graduate. One course was part of a certificate. Only six courses were mandatory courses as part of a larger structure, primarily as part of a minor $(n=3)$, others $(n=8)$ satisfied degree requirements but were optional; four courses were a rotating topics course or electives that were not housed within a specific program and the remaining $(\mathrm{n}=2)$ were unlisted.

Although it was difficult to determine which courses were introductory or upper level due to inconsistencies between institutions, six courses required prerequisites whereas nine did not list prerequisites. 


\section{Syllabi analysis}

The fifteen syllabi in our sample were uploaded into NVivo Qualitative Data Analysis Software Version 12.6.0. We focused our analysis on content areas, course goals, and learning outcomes. We conducted a thematic analysis of weekly topics and reading lists when available (twelve syllabi included reading lists) using an inductive approach (Mills et al., 2010). In practice, instructors use the terms goals, objectives, and outcomes interchangeably; for the purposes of our analysis, we identified learning goals as broad statements that described long-term understanding and accomplishments (Wiggins \& McTighe, 2005, p. 14). We identified learning outcomes as statements that indicated short-term, measurable knowledge and skills that learners were expected to acquire by the end of the course (Wiggins \& McTighe, 2005, p. 14).

Seventeen content area themes were identified through analysis of weekly topics and reading lists stated in syllabi (see Table 2$)$. The course goals $(n=49)$ and learning outcomes (LOs) $(n=123)$ were independently analyzed by two of the authors coding for key themes in the dataset. We followed the coding process outlined by Guest et al. (2012) that relies on coding for themes based on analytic objectives. In our case, the analytic objectives are statements that indicate course goals and learning outcomes in our sample of syllabi to align with research question two. A subsequent coding framework was agreed upon resulting in seven course goals (Table 3) and eight learning outcomes (Table 4) thematic areas. A final round of analysis was conducted based on Stage 1 (Desired Results) of the UbD framework (Wiggins \& McTighe, 2005), separating course goals into the categories of transfer and meaning, and learning outcomes into declarative and procedural knowledge (Table 5). 
Results

Table 2: Content area themes in syllabi $(n=15)$

\begin{tabular}{|l|c|}
\hline \multicolumn{1}{|c|}{ Theme } & Present in Syllabi (\%) \\
\hline Defining Food Justice & 100 \\
\hline Case Studies of Current Food Justice Projects & 93 \\
\hline Agriculture, Husbandry \& Fisheries & 87 \\
\hline Built Food Environment & 87 \\
\hline Food (In)security & 87 \\
\hline Food Governance & 87 \\
\hline Class & 80 \\
\hline Food Policy \& Planning & 80 \\
\hline Labour & 80 \\
\hline Economic Systems & 73 \\
\hline Environment \& Ecosystem & 73 \\
\hline Food Movements & 67 \\
\hline Race & 60 \\
\hline Diet, Nutrition \& Human Health & 53 \\
\hline Gender & 47 \\
\hline Decolonizing Food Systems and Indigenous Food Sovereignty & 33 \\
\hline Intersectionality & 27 \\
\hline & \\
\hline
\end{tabular}

Table 3: Course goals and frequency of occurrence

\begin{tabular}{|l|c|l|l|}
\hline Theme & $\begin{array}{c}\text { Frequency } \\
(\mathrm{n}=49)\end{array}$ & Definition & Example \\
\hline & $\begin{array}{l}\text { Students are familiar with and able to } \\
\text { connect organizing frameworks (e.g., food } \\
\text { sovereignty, food insecurity, food security, } \\
\text { right to food) and lenses used to explore } \\
\text { food systems topics (e.g., critical race } \\
\text { theory) to food justice issues and projects. }\end{array}$ & $\begin{array}{l}\text { "Encourage you to consider the concepts of food } \\
\text { security and justice in economic, political, social and } \\
\text { cultural contexts. " }\end{array}$ \\
\hline $\begin{array}{l}\text { Conceptual } \\
\text { Frameworks }\end{array}$ & $38 \%$ & & \\
\hline
\end{tabular}




\begin{tabular}{|c|c|c|c|}
\hline $\begin{array}{l}\text { Spatial } \\
\text { Scales }\end{array}$ & $28 \%$ & $\begin{array}{l}\text { Students recognize the different histories, } \\
\text { power relations, and strategies for } \\
\text { dismantling systems of oppression at local, } \\
\text { regional, national, and global scales. }\end{array}$ & $\begin{array}{l}\text { "Analyze food justice organizations/movements } \\
\text { struggling to create healthy and sustainable food } \\
\text { systems locally, bioregionally and globally." }\end{array}$ \\
\hline $\begin{array}{l}\text { Food } \\
\text { Systems }\end{array}$ & $26 \%$ & $\begin{array}{l}\text { Students recognize different } \\
\text { components/nodes of the food system. }\end{array}$ & $\begin{array}{l}\text { "Delve into the environmental, economic, health, } \\
\text { cultural, and social impacts of how food is grown, } \\
\text { processed, manufactured, distributed, sold, and } \\
\text { consumed in the U.S." }\end{array}$ \\
\hline $\begin{array}{l}\text { Skills, } \\
\text { broadly }\end{array}$ & $26 \%$ & $\begin{array}{l}\text { Students develop and apply skills related to } \\
\text { advocacy, interdisciplinarity, and systemic } \\
\text { thought. }\end{array}$ & $\begin{array}{l}\text { "Focus on building student's knowledge and skills } \\
\text { in advocacy in order to help promote healthier, } \\
\text { more sustainable, and more equitable food } \\
\text { systems." }\end{array}$ \\
\hline (In)equity & $24 \%$ & $\begin{array}{l}\text { Students examine the historical } \\
\text { development of inequities, contemporary } \\
\text { manifestations, and how they are } \\
\text { reproduced, resisted, or contested. }\end{array}$ & $\begin{array}{l}\text { "Examines how our food system has been } \\
\text { restructured over the last century to benefit large- } \\
\text { scale agriculture interests, creating a global food } \\
\text { system that emphasizes convenience and fast-food } \\
\text { solutions for consumers, often to the detriment of } \\
\text { low-income people and communities of color." }\end{array}$ \\
\hline $\begin{array}{l}\text { Call to } \\
\text { Action }\end{array}$ & $22 \%$ & $\begin{array}{l}\text { Students are aware of approaches opposing } \\
\text { structural inequity and work with } \\
\text { community organizations to create just food } \\
\text { systems alternatives. }\end{array}$ & $\begin{array}{l}\text { "Study and help create an ecologically regenerative } \\
\text { local food system and economy in the region that } \\
\text { empowers and healthfully feeds all of its people." }\end{array}$ \\
\hline $\begin{array}{l}\text { Social } \\
\text { Movements }\end{array}$ & $20 \%$ & $\begin{array}{l}\text { Students are aware of past and current } \\
\text { examples of social movements involved in } \\
\text { food justice projects and their common } \\
\text { strategies and patterns of resistance. }\end{array}$ & $\begin{array}{l}\text { "Examines the vibrant and growing range of social } \\
\text { movements around food and agriculture, with an } \\
\text { emphasis on the global South (or Third World)." }\end{array}$ \\
\hline
\end{tabular}

Table 4: Learning outcomes and frequency of occurrence

\begin{tabular}{|l|c|l|l|}
\hline Code & Frequency (n=123) & Definition & Example \\
\hline Advocacy & $33 \%$ & $\begin{array}{l}\text { Advocate for development of just and } \\
\text { sustainable food systems through discussion, } \\
\text { collaboration, data collection, analysis, and } \\
\text { dissemination. }\end{array}$ & $\begin{array}{l}\text { "Cultivate analytic, discussion, public } \\
\text { speaking, research, and writing skills." }\end{array}$ \\
\hline In)equity & $27 \%$ & $\begin{array}{l}\text { Recognize historical roots of social inequities } \\
\text { and how they manifest in current food } \\
\text { systems. }\end{array}$ & $\begin{array}{l}\text { "Identify how and why low-income } \\
\text { communities of color are } \\
\text { disproportionately affected by market and } \\
\text { policy failures to produce and distribute } \\
\text { healthy, safe food." }\end{array}$ \\
\hline Food Systems & $20 \%$ & $\begin{array}{l}\text { Analyze inequities within food systems, } \\
\text { including in agriculture, processing, } \\
\text { distribution, and consumption of food. }\end{array}$ & $\begin{array}{l}\text { "Identify the different actors in food } \\
\text { politics and the varying/conflicting ideas } \\
\text { and intentions around food production, } \\
\text { distribution, and access as it relates to } \\
\text { equity." }\end{array}$ \\
\hline
\end{tabular}




\begin{tabular}{|c|c|c|c|}
\hline $\begin{array}{l}\text { Community- } \\
\text { Based } \\
\text { Collaboration }\end{array}$ & $17 \%$ & $\begin{array}{l}\text { Contribute to community-based } \\
\text { collaborations and multi-stakeholder } \\
\text { engagements. }\end{array}$ & $\begin{array}{l}\text { "Enhance your community research skills } \\
\text { and methods and offer research services } \\
\text { needed by local-food initiatives in your } \\
\text { area." }\end{array}$ \\
\hline Alternatives & $16 \%$ & $\begin{array}{l}\text { Evaluate the effectiveness of initiatives that } \\
\text { are working towards solutions to address } \\
\text { inequities and structural issues. }\end{array}$ & $\begin{array}{l}\text { "Investigate organizations of their choice } \\
\text { that are working to remedy inequitable } \\
\text { power relations in the food system and } \\
\text { will present their findings to the rest of } \\
\text { the class." }\end{array}$ \\
\hline Spatial Scale & $13 \%$ & $\begin{array}{l}\text { Interpret food justice issues, projects, and } \\
\text { outcomes at different spatial and } \\
\text { geographical scales. }\end{array}$ & $\begin{array}{l}\text { "Research and describe local, regional } \\
\text { and global social movements around food } \\
\text { justice." }\end{array}$ \\
\hline $\begin{array}{l}\text { Critical } \\
\text { Reflection }\end{array}$ & $11 \%$ & $\begin{array}{l}\text { Connect topics and issues to one's own lived } \\
\text { experience, professional development, and } \\
\text { future work. }\end{array}$ & $\begin{array}{l}\text { "Engage in one's own reflection, applying } \\
\text { the frameworks and approaches studied } \\
\text { to one's own everyday life, experiences, } \\
\text { and social context." }\end{array}$ \\
\hline $\begin{array}{l}\text { Define Food } \\
\text { Justice }\end{array}$ & $10 \%$ & $\begin{array}{l}\text { Determine how and why a project or } \\
\text { initiative relates to food justice. }\end{array}$ & $\begin{array}{l}\text { "Define food justice and explore where } \\
\text { and how it connects to ourselves and our } \\
\text { communities." }\end{array}$ \\
\hline
\end{tabular}


Table 5: Stage 1 of Understanding by Design (UbD)

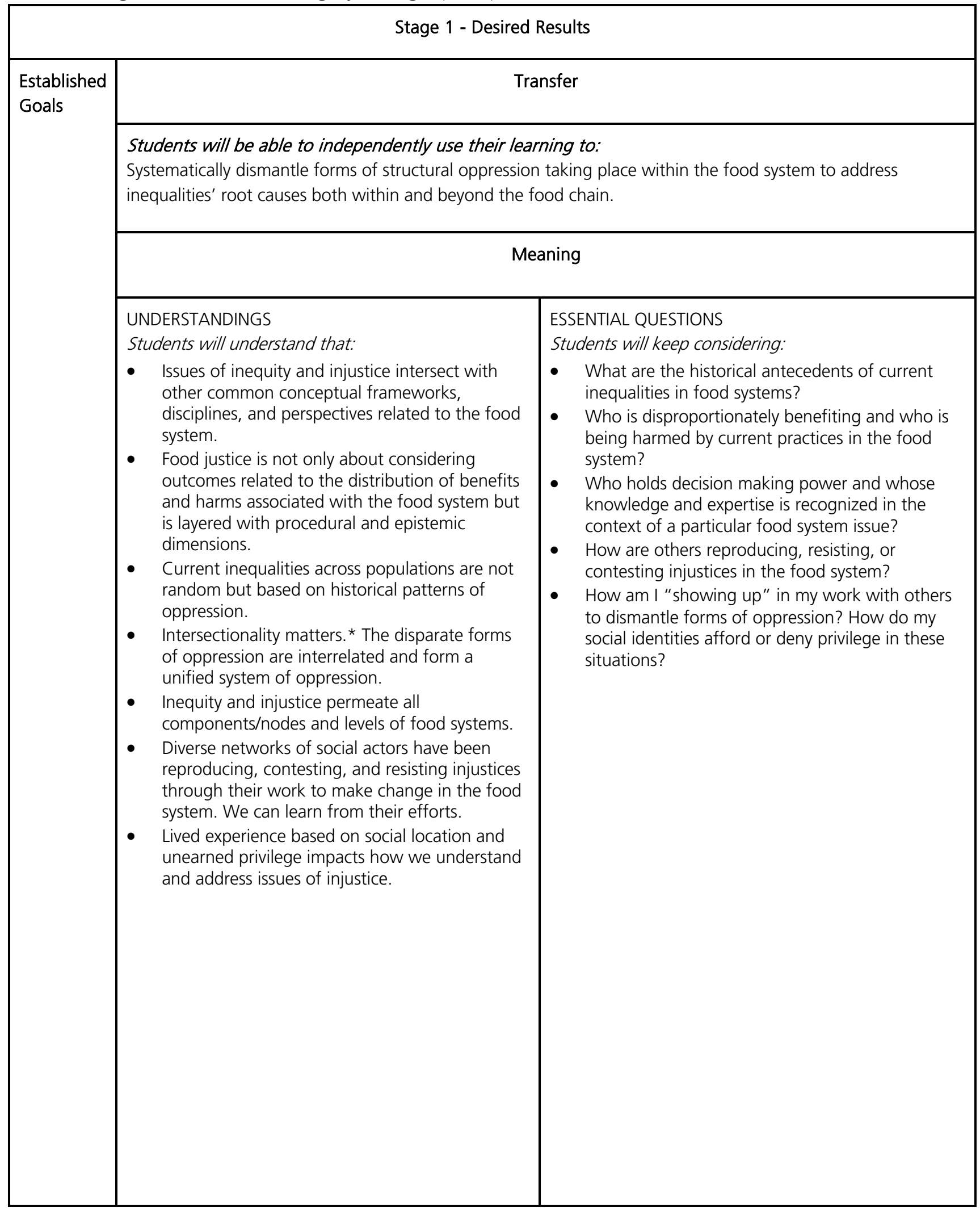




\begin{tabular}{|c|c|}
\hline \multicolumn{2}{|c|}{ Acquisition } \\
\hline $\begin{array}{l}\text { Students will know: } \\
\text { - Definition of food justice and justice theory* } \\
\text { - Definitions of forms of oppression and related } \\
\text { terms, such as racism, classism, sexism, } \\
\text { xenophobia, colonialism, and white } \\
\text { supremacy. * } \\
\text { Definitions of key concepts related to food } \\
\text { systems (e.g., food insecurity, food security, } \\
\text { food sovereignty) and how they connect to food } \\
\text { justice. } \\
\text { Historical events, legislation, and policies that } \\
\text { led to the oppression of specific groups. } \\
\text { Characteristics that define components/nodes of } \\
\text { the food system. } \\
\text { Examples of historical and current projects that } \\
\text { reproduce, resist, and confront injustice in the } \\
\text { food system. }\end{array}$ & 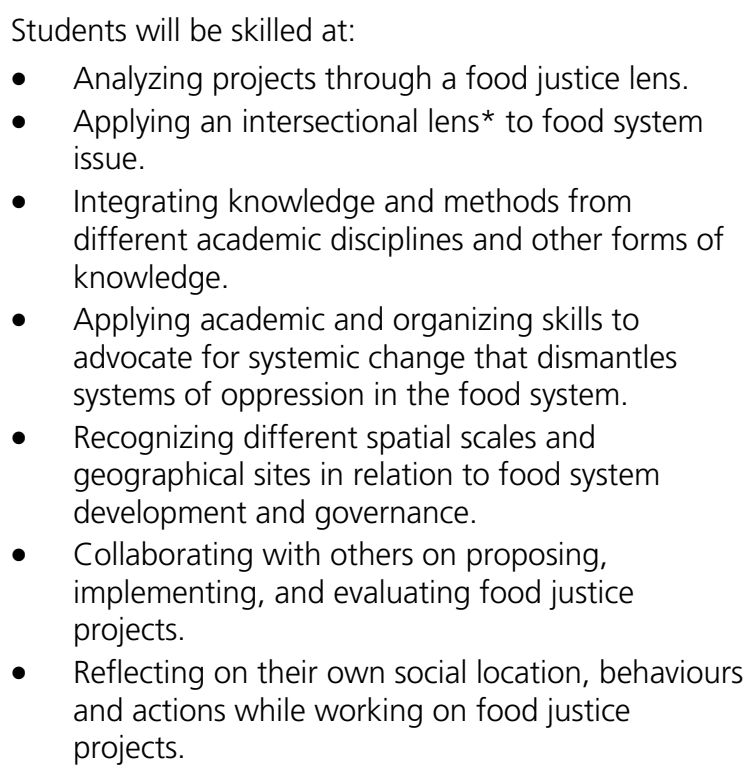 \\
\hline
\end{tabular}

* Denotes terms that are absent from our syllabi analysis but prominent in food justice scholarship.

\section{Discussion}

In the following section, we discuss content areas in relation to food justice scholarship, focusing on what is present, underrepresented, and absent. In consideration of Table 5, which positions course goal and learning outcome themes into the Stage 1 template of the UbD framework, we consider the need for established goals within which to situate food justice courses, challenges of course scope, value of scaffolding goals and outcomes across programs, and future directions for developing Stages 2 and 3 of the UbD framework to align potential indicators of understanding and learning activities.

\section{Content areas}

Glennie and Alkon's (2018) evidence-based review of food justice scholarship revealed that the field is highly interdisciplinary and organized around three central axes: social movement activism, the development of alternative food practices, and analyses of inequalities in conventional and alternative food systems. Glennie and Alkon (2018) identified case studies as the most commonly used methodological approach in food justice related peer-reviewed articles. 
The content area themes articulated in Table 2 demonstrate a strong correspondence to the findings of Glennie and Alkon's (2018) review.

The courses in our sample integrate a broad range of disciplinary perspectives, make explicit use of case studies of social movements and alternative food practices, and centre inequalities in conventional and alternative food systems. Based on our analysis of weekly topics and readings, class and labour issues receive more attention in our sample, which also follows a pattern identified in Glennie and Alkon's (2018) review, where at the outset of the development of food justice scholarship, class and labour were more prominent lenses through which injustices were framed. There is a similar correspondence in course content to Cadieux and Slocum's (2015) and Horst's (2017) categories of food justice practice, which emphasize orientation towards and intervening in the areas of trauma/inequity, land, labour, exchange, and governance. Apart from trauma/inequity (which we will return to later in the discussion), content in these areas have the highest frequency in weekly topics and readings in our sample of syllabi.

Topics and readings related to race (60\% frequency) were less prominent in our analysis of course content. The lower occurrence of race is somewhat surprising. As Slocum (2018) notes, "the concept of food justice rose out of a mobilisation against structural racism in the food system and the whiteness of the local food movement" (p. 1103). Further, it has long been acknowledged that "race is the modality in which class is lived" (Hall et al., 1978, p. 394). An emphasis on class and labour (both with frequencies of $80 \%$ ) in course content with a lower frequency of content related to race is conceptually limiting and problematic. Topics related to gender were even less prominent at a frequency of $47 \%$. Recent scholarship on feminist perspectives in food studies (Parker et al., 2019) are rich resources for teaching and learning about gender and social oppression in the food system. As Julier (2019) argues, the inclusion of feminist perspectives in food-related courses is a necessity if we are serious about transforming food systems towards more socially just alternatives. Content related to decolonization and Indigenous food sovereignty are similarly less prominent (33\%) in our sample. An understanding of settler colonialism in North America- "the elimination of the Native [and] the naturalization of unnatural settler states built on the annexation of Indigenous land and the genocide of Indigenous people" (Estes \& Dunbar-Oritz, 2020, p. 3)-is foundational to the various expressions of oppression in food justice scholarship and activism. Within institutes of postsecondary education in Canada and the United States, content related to decolonization and Indigenous food sovereignty ought to be at the forefront. Indigenous Food Systems: Concepts, Cases, and Conversations is an excellent resource for exploring these issues (Settee \& Shukla, 2020). Although issues of class, race, gender, and colonialism appeared within course syllabi in our sample (at relative unequal frequency), topics related to intersectionality were similarly less prominent (27\%). Cho and colleagues (2013) note that intersectionality focuses "attention on the vexed dynamics of difference and the solidarities of sameness in the context of antidiscrimination and social movement politics...[exposing] how single-axis thinking undermines legal thinking, disciplinary knowledge production, and struggles for social justice" (p. 787). 
As emphasized by Julier (2019), teaching intersectional analysis in food-related programs is difficult, often resulting in one dimension being emphasized without close attention to the intersections, which leads to oppression-a contradictory outcome of a food justice course.

The following were notably absent from weekly topics and course readings: white supremacy, (anti-)Blackness, explicit justice theories, and trauma. White supremacy, defined as "the presumed superiority of white racial identities, however problematically defined, in support of the cultural, political, and economic domination of non-white groups" (Bonds \& Inwood, 2016, pp. 719-720), was absent in our analysis of syllabi. Recognizing how the logic, dialectic, and performance of white supremacy underwrites settler colonialism, racial capitalism, patriarchy, and other forms of social oppression is central to efforts towards interrupting the reproduction of white hegemony (Slocum, 2007; Slocum \& Saldanha, 2016; Bonds \& Inwood, 2016). In connection to this, few courses engaged with the concept of anti-Blackness within the food system or highlighted the erasure of Black contributions to agriculture and food movements. Specific mention of Black food culture as it relates to food justice was only present in one course at the weekly topic level. While the topic of Blackness may be referenced within the context of racial justice, it is essential to: build a nuanced understanding of Blackness as it relates to the food system, evaluate the unique impacts of the historical traumas of slavery, and to move past an inclusion rhetoric that fails to address present power dynamics (Ramírez, 2015 Reese \& Garth, 2020). Many academics have previously highlighted the inequities within the food system that disproportionally affects those of African American descent and the variety of ways Black people contribute to, work towards, and embody food justice and seek to counter this erasure, see Black Food Matters (Garth \& Reese, 2020) and Freedom Farmers (White, 2018).

Defining food justice was present as a topic in all syllabi in our sample, however, explicit links to justice theories were absent. Twelve of fifteen syllabi included citations for weekly readings, however, no reading list cited resources related specifically to justice theory, instead relying on the works of scholars specifically addressing justice from a food perspective. Slocum (2018) states clearly that it is in our collective best interests to recognize and state which theory of justice "lies implicit in the cases we study" (p. 1103), lest our efforts contribute to the depoliticization of the term. For example, Cadieux and Slocum (2015) draw on the work of Young $(1997)$ and Fraser $(1995,2008)$ to ground their arguments for food justice theory and practice in the United States. Lastly, as emphasized by Slocum and Cadieux (2015), understanding and taking action towards equity "needs to be paired with a recognition of the experience of trauma" (p. 13). The concept of trauma relates to individual, collective, cultural, and intergenerational experiences of exploitation, marginalization, powerlessness, cultural imperialism, and violence (Methot, 2019). Slocum and Cadieux (2015) acknowledge that they approach this term with caution, however, "trauma brings the urgency of past and ongoing harm into the food movement's work...suggesting that food justice cannot settle for promoting mere resilience in the face of a long, slow war against marginalized people, a war that some within the food movement do not recognize" (p. 33). 
We include mention of trauma within the context of food justice curriculum development with caution as well, and do not suggest instructors attempt to incorporate trauma-informed pedagogy without adequate consideration of the potentially serious affective impacts on learners. As explained by Carello and Butler (2014), there is considerable risk of retraumatizing and secondary traumatization in postsecondary classrooms when presenting traumatic material in the form of texts and films.

\section{Articulating clear course goals and learning outcomes}

In our analysis of food justice syllabi, course goals, objectives, and outcomes were not consistently stated in a manner that reflects the use of these terms in scholarship related to instructional design. First, potential benefits of positioning the course goal and learning outcome themes in the Stage 1 include more accurate distinction between long-term goals and short-term, measurable outcomes. Second, Table 5 contains concise statements that can be adopted by those currently teaching food justice courses or by instructors interested in developing a new food justice course. Third, by displaying the course goal and learning outcome themes in a table, it is easier to recognize the fundamental elements of a food justice course and how they connect to the growing scholarship of teaching and learning related to food studies, critical food pedagogy, critical food system education, critical education for food systems transformation, and sustainable food systems education. However, missing from Table 5 is a statement related to established goals from external design standards, such as mission-related goals, program-level learning objectives, or graduate attributes articulated in a field's scholarship of teaching and learning. Although the field of food justice has a history of activism and a growing scholarship, there does not exist a collective statement from scholars, activists, and instructors articulating exit-level objectives or graduate attributes. As emphasized by Wiggins and McTighe (2005), "with no long-term goals, there is no perspective-hence no check on the teacher habit of merely teaching to short-term, content-related objectives" (p. 56). In a field as diverse as food justice, it may be difficult to create agreed upon statements that can adequately capture long-term objectives; however, it is worth considering as an output of future scholarship, either through peer-reviewed publications, conference workshops, or gatherings connected to grassroots and activist networks. We hope that the content of Table 5 can be a useful starting point towards such a goal.

\section{Course scope}

Based on our integration of themes from syllabi into Stage 1 of the UbD framework (and our own experience as instructors of food justice related courses), we believe it is prudent to acknowledge course scope. 
The content areas, course goals, and learning outcomes are incredibly diverse and ambitious. Is it realistic to expect student achievement of the stated learning outcomes and course goals over the typical thirteen-to-fifteen-week duration of a postsecondary course? Taking into account the interdisciplinary and methodological landscapes of food justice scholarship, the analysis of social movements, the development of effective advocacy skills, the awareness of historical and current forms of inequity, intersectional analysis of social oppression, familiarity with food systems nodes and components at local, national, and global scales, awareness of one's own social location, and meaningful contributions to community-based food justice projects, these are high expectations to meet for any individual course. Nine courses in our sample did not list prerequisite requirements, meaning students could likely enroll in the course without having encountered content or developed skills related to the field of food justice. As suggested by Bauer and Clancy (2018), it is important to scaffold "content and pedagogy to strategically expand students' zones of comfort from very personal experiences with the material to broader groups of people and course concepts" (p. 72). To achieve the higher-order learning outcomes and goals stated in our sample of food justice courses and articulated in Table 5 , it is ideal for students to have developed fundamental knowledge and skills in a food-related discipline, encountered basic definitions related to social justice issues, have experience learning in a community setting, and have had the opportunity to consider and reflect upon their own social location and identities. We suggest that in the process of developing or refining a food justice course, instructors consider what other knowledge and skills are being developed within a degree program to have a better sense of student preparedness to engage in content and processes related to food justice courses. Or, if possible, instructors could consider developing a series of food justice courses to introduce basic concepts, explore case studies of social movements, and provide students with low-risk/low-ask engagement opportunities with community organizations. Ideally, we would be able to intentionally scaffold the fundamental knowledge and skills across a four-year program so that course goals and learning outcomes described in Table 5 are offered to senior undergraduate students that have had opportunities to learn, explore, question, reflect, and engage more deeply with activists and community-based organizations involved in food justice work. By asking too much of our students, likely out of a sense of urgency and lack of further opportunity, we may end up failing to do "justice" to the field and potentially send underprepared students into collaborations with community organizations.

\section{Conclusion}

There is a growing prevalence of NGOs and other grassroots "food justice" organizations offering educational programs related to issues of injustice within the food system, mirroring the growth in the use of the term "food justice". 
For example, in a recent list of food justice organizations by Food Tank, of the twentyfour organizations listed, at least eleven had an emphasis on education related to food justice based on the synopsis from Food Tank (Nierenburg \& Howell, 2020). Furthermore, as mentioned previously, $57 \%$ of food justice organizations stated food systems education as a key goal (Hislop, 2014). Our findings provide a useful starting point for designing food justice curriculum using the Understanding by Design framework by starting with the desired results outlined (Table 5) and working backwards to design assessments and activities.

While this paper offers a first response of understanding how food justice is being taught, further research must investigate other framings to enrich our understanding of food justice pedagogy. Based on our initial research we recommend the following approaches: 1) analyzing how food justice concepts manifest at the program-level based on our initial framework or 2) conducting an environmental scan of all courses related to food for presence of social justice issues. By investigating at the course level, it may be determined if courses are scaffolding the ambitious course goals (present in Table 3) across different courses and if a collective "Established Goal" (Table 5) has emerged. For the second approach, a more expansive study will help shape our collective understandings of food justice, as many instructors are likely teaching at the intersection of the course themes (Table 2), however, not explicitly identifying their courses as "social justice" or "food justice" courses.

We end with a call for further scholarship related to Stage 2 (Evidence) and Stage 3 (Learning Plan) of the UbD framework. What are indicators that demonstrate successful acquisition of knowledge and skills in food justice courses? And what types of learning activities effectively support student development in this field? As Table 5 demonstrates, food justice courses are complex and ambitious. Current instructors in food-related fields likely have resources, activities, and assignments that they have tested in their classrooms and feel confident that they help achieve similar learning outcomes. The sharing of educational practices will increase our collective effectiveness to support our students as they develop the capacities to systematically dismantle forms of structural oppression taking place within the food system to address inequality's root causes both within and beyond the food chain.

\section{References}

Alkon, A.H., \& Agyeman, J. (Eds.). (2011). Cultivating food justice: Race, class, and sustainability. MIT Press. https://mitpress.mit.edu/books/cultivating-food-justice

Allen, P. (2008). Mining for justice in the food system: Perceptions, practices, and possibilities. Agriculture and Human Values, 25(2), 157-161. https://doi.org/10.1007/s10460-008-9120$\underline{6}$

Allen, P., \& Sachs, C. (2012). Women and food chains: The gendered politics of food. In P.W. Forson \& C. Counihan (Eds.), Taking food public: Redefining foodways in a changing 
world. Routledge. https://www.routledge.com/Taking-Food-Public-Redefining-Foodwaysin-a-Changing-World/Williams-Forson-Counihan/p/book/9780415888554

Anderson, M.D. (2013). Higher education revisited: Sustainability science and teaching for sustainable food systems. In R. Braun, J. Pippig, F. Mari, \& Z. Heuschkel (Eds.), Future of food: State of the art, challenges and options for action. Oekom. https://www.oekom.de/buch/future-of-food-9783865814197?p=1

Anderson, C.R., Brady, J., \& Levkoe, C.Z. (Eds.). (2016). Conversations in food studies. University of Manitoba Press. https://uofmpress.ca/books/detail/conversations-in-food$\underline{\text { studies }}$

Anderson, C.R., Binimelis, R., Pimbert, M.P., \& Rivera-Ferre, M.G. (2019). Introduction to the symposium on critical adult education in food movements: Learning for transformation in and beyond food movements - The why, where, how and the what next? Agriculture and Human Values, 36(3), 521-529. https://doi.org/10.1007/s10460-019-09941-2

Bauer, K., \& Clancy, K. (2018). Teaching race and social justice at a predominantly white institution. Journal of Political Science Education, 14(1), 72-85. https://doi.org/10.1080/15512169.2017.1358175

Berg, J., Nestle, M., \& Bentley, A. (2003). Food studies. In S.H. Katz \& W.W. Weaver (Eds.), The Scribner encyclopedia of food and culture (Vol. 2, pp. 16-18). Charles Scribner and Sons.

https://www.cengage.com/search/productOverview.do? Ntt=Encyclopedia + of + Food + and + Culture\%2C+1st+Edition|2030501053327033541884320081462496903\&N=197\&Nr=197 $\underline{\& N t k=A P G \% 7 C P \_ \text {EPI\&Ntx }=\text { mode }+ \text { matchallpartial }}$

Boger R., Low, R.D., \& Potter, A.E. (2019). Tackling the wicked problem of global food security: Engaging undergraduates through ArcGIS online. In D. Gosselin, A. Egger \& J. Taber (Eds.), Interdisciplinary teaching about Earth and the environment for a sustainable future (pp. 159-177). Springer. https://doi.org/10.1007/978-3-030-03273-9 \&

Bonds, A., \& Inwood, J. (2016). Beyond white privilege: Geographies of white supremacy and settler colonialism. Progress in Human Geography, 40(6), 715-733. https://doi.org/10.1177\%2F0309132515613166

Bradley, K., \& Herrera, H. (2016). Decolonizing food justice: Naming, resisting, and researching colonizing forces in the movement. Antipode, 48(1), 97-114. https://doi.org/10.1111/anti.12165

Brundiers, K., \& Wiek, A. (2017). Beyond interpersonal competence: Teaching and learning professional skills in sustainability. Education Sciences, 7(1), 39. https://doi.org/10.3390/educsci7010039 
Butterwick, S. (2005). Feminist pedagogy. In L.M. English (Ed.), International encyclopedia of adult education (pp.530-533). Palgrave Macmillan. https://www.palgrave.com/gp/book/9781403917355

Cadieux, K.V., \& Slocum, R. (2015). What does it mean to do food justice? Journal of Political Ecology, 22, 1-26. https://digitalcommons.hamline.edu/cla faculty/3

Carello, J., \& Butler, L.D. (2014). Potentially perilous pedagogies: Teaching trauma is not the same as trauma-informed teaching. Journal of Trauma \& Dissociation, 15(2), 153-168. https://www.researchgate.net/deref/http\%3A\%2F\%2Fdx.doi.org\%2F10.1080\%2F 1529973 2.2014.867571

Cargill, K. (2005). Food studies in the curriculum: A model for interdisciplinary pedagogy. Food, Culture \& Society, 8(1), 115-123. https://doi.org/10.2752/155280105778055371

Cho, S., Crenshaw, K.W., \& McCall, L. (2013). Toward a field of intersectionality studies: Theory, applications, and praxis. Signs: Journal of women in culture and society, 38(4), 785-810. https://doi.org/10.1086/669608

Chornyak, B. (2015). Teaching systems thinking through food. In R. Vande Zande, E. Bohemia, \& I. Digranes (Eds.), Proceedings of the 3rd international conference for design education researchers (Vol. 1, p. 45-56). Aalto University. DOI: 10.13140/RG.2.1.1200.7520

Creswell, J.W. (2014). Chapter 9: Qualitative methods. In Research design: Qualitative, quantitative, and mixed methods approaches (4th ed.). SAGE Publications.

Daigle, M. (2019). Tracing the terrain of Indigenous food sovereignties. The Journal of Peasant Studies, 46(2), 297-315. https://doi.org/10.1080/03066150.2017.1324423

Desmarais, A.A., \& Wittman, H. (2014). Farmers, foodies and First Nations: Getting to food sovereignty in Canada. The Journal of Peasant Studies, 41(6), 1153-1173. https://doi.org/10.1080/03066150.2013.876623

Ebel, R., Ahmed, S., Valley, W., Jordan, N., Grossman, J., Byker Shanks, C., Stein, M., Rogers, M., \& Dring, C. (2020). Co-design of adaptable learning outcomes for sustainable food systems undergraduate education. Frontiers in Sustainable Food Systems: Social Movements, Institutions and Governance.

Estes, N., \& Dunbar-Ortiz, R. (2020). Examining the wreckage. Monthly Review, 72(3), 1-7. https://monthlyreview.org/2020/07/01/examining-the-wreckage/

Finger, M. (2005). Critical theory. In L.M. English (Ed.), International Encyclopedia of Adult Education, (pp. 165-168). Palgrave Macmillan. https://doi.org/10.1007/978-1-349-72520-5

Flowers, R., \& Swan, E. (2012). Eating the Asian other? Pedagogies of food multiculturalism in Australia. PORTAL Journal of Multidisciplinary International Studies, 9, 1-30. https://doi.org/10.5130/portal.v9i2.2370 
Flowers, R., \& Swan, E. (2015). Food pedagogies: Histories, definitions and moralities. In R. Flowers \& E. Swan (Eds.), Food pedagogies. Ashgate.

Fraser, N. (1995). Recognition or redistribution? A critical reading of Iris Marion Young's 'justice and the politics of difference'. Journal of Political Philosophy 3(2): 166-180. doi: 10.1111/j.1467-9760.1995.tb00033.x

Fraser, N. (2008). Abnormal justice. Critical Inquiry 34(3): 393-422. doi: 10.1086/589478

Galt, R.E., Clark, S.F., \& Parr, D. (2012). Engaging values in sustainable agriculture and food systems education: Toward an explicitly values-based pedagogical approach. Journal of Agriculture, Food Systems, and Community Development, 2(3), 43-54. https://foodsystemsjournal.org/index.php/fsj/article/view/108

Garth, H., \& Reese, A.M. (Eds.). (2020). Black Food Matters: Racial justice in the Wake of Food Justice. University of Minnesota Press. https://www.upress.umn.edu/bookdivision/books/black-food-matters

Gibb, N., \& Wittman, H. (2013). Parallel alternatives: Chinese-Canadian farmers and the metroVancouver local food movement. Local Environment, 18,1-19. DOI: $10.1080 / 13549839.2012 .714763$

Glennie, C., \& Alkon, A.H. (2018). Food justice: cultivating the field. Environmental Research Letters, 13(7), 073003. https://doi.org/10.1088/1748-9326/aac4b2

Gottlieb, R., \& Joshi, A. (2010). Food Justice. The MIT Press. http://muse.jhu.edu/book/22133

Graham, P., Evitts, T., \& Thomas-MacLean, R. (2008). Environmental scans. Canadian Family Physician, 54(7), 1022-1023. https:/www.ncbi.nlm.nih.gov/pmc/articles/PMC2464800/

Guest, G., MacQueen, K., \& Namey, E. (2012). Chapter 3: Themes and codes. In Applied Thematic Analysis. SAGE Publications. https://doi.org/10.4135/9781483384436

Hall, S., Clarke, J., Critcher, C., Jefferson, T., \& Roberts, B. (1978). Policing the crisis: Mugging, the state and law and order. Macmillan Press.

Hamada, S., Wilk, R., Logan, A., Minard, S., \& Trubek, A. (2015). The future of food studies. Food, Culture \& Society, 18(1), 167-186. https://doi.org/10.2752/175174415X14101814953846

Hartle, J.C., Cole, S., Trepman, P., Chrisinger, B.W., \& Gardner, C.D. (2017). Interdisciplinary food-related academic programs: A 2015 snapshot of the United States landscape. Journal of Agriculture, Food Systems, and Community Development, 7(4), 35. https://doi.org/10.5304/jafscd.2017.074.006

Herman, A., Goodman, M.K., \& Sage, C. (2018). Six questions for food justice. Local Environment, 23(11), 1075-1089. https://doi.org/10.1080/13549839.2018.1532401 
Hislop, R.S. (2014). Reaping equity: A survey of food justice organizations in the USA (Publication No. 1590830) [Masters Thesis, University of California, Davis]. PQDT Open. https://pqdtopen.proquest.com/doc/1695282787.html?FMT=ABS

Holt-Giménez, E., \& Wang, Y. (2011). Reform or transformation? The pivotal role of food justice in the U.S. food movement. Race/Ethnicity: Multidisciplinary Global Contexts, 5(1), 83-102. https://doi.org/10.2979/racethmulglocon.5.1.83

Holt-Giménez, E. (2016). Racism and capitalism: Dual challenges for the food movement. Journal of Agriculture, Food Systems, and Community Development, 5(2), 23-25. https://doi.org/10.5304/jafscd.2015.052.014

Horst, M. (2017). Food justice and municipal government in the USA. Planning Theory \& Practice, 18(1), 51-70. https://doi.org/10.1080/14649357.2016.1270351

Jordan, N., Grossman, J., Lawrence, P.G., Harmon, A.H., Dyer, W.E., Maxwell, B.D., Cadieux, K.V., Galt, R., Rojas, A., Byker Shanks, C., Ahmed, S., Bass, T., Kebreab, E., Singh, V., Michaels, T., \& Tzenis, C. (2014). New curricula for undergraduate food-systems education: A sustainable agriculture education perspective. Nacta Journal, 58(4), 302-310. https://scholarworks.montana.edu/xmlui/handle/1/9118

Julier, A. (2019). Critiquing hegemony, creating food, crafting justice: Cultivating an activist feminist food studies. In B. Parker, J. Brady, E. Power \& S. Belyea (Eds.), Feminist food studies (pp. 13-32). Canadian Scholars' Press.

Kipp, A., Cunsolo, A., Gillis, D., Sawatzky, A., \& Harper, S.L. (2019). The need for communityled, integrated and innovative monitoring programmes when responding to the health impacts of climate change. International Journal of Circumpolar Health, 78(2). https://doi.org/10.1080/22423982.2018.1517581

Koç, M., Sumner, J., \& Winson, A. (Eds.). (2012). Critical perspectives in food studies. Oxford University Press.

Levkoe, C.Z., Hammelman, C., Reynolds, K., Brown, X., Chappel, J.M., Salvador, R., \& Wheeler, B. (2020). Scholar-activist perspectives on radical food geography: Collaborating through food justice and food sovereignty praxis. Human Geography, 13(3), 293-304. https://doi.org/10.1177/1942778620962036

Lloro-Bidart, T. (2019). Intersectional and interdisciplinary approaches to interspecies food justice pedagogies. In T. Lloro-Bidart \& V. Banschbach (Eds.), Animals in environmental education (pp. 53-76). Palgrave Macmillan.

Loopstra, R., \& Tarasuk, V. (2013). Severity of household food insecurity is sensitive to change in household income and employment status among low-income families. The Journal of Nutrition, 143(8), 1316-1323. https://doi.org/10.3945/jn.113.175414 
Loya, K.I. (2020). Creating inclusive college classroom: Granting epistemic credibility to learners. In L. Parson \& C.C. Ozaki (Eds.), Teaching and learning for social justice and equity in higher education (pp. 117-135). Palgrave Macmillan. https://www.palgrave.com/gp/book/9783030449384

Mares, T.M., \& Peña, D.G. (2011). Environmental and food justice. In A.H. Alkon \& J. Agyeman (Eds.), Cultivating food justice: Race, class, and sustainability (pp. 197-220). MIT Press. https://mitpress.mit.edu/books/cultivating-food-justice

Meek, D., \& Tarlau, R. (2015). Critical food systems education and the question of race. Journal of Agriculture, Food Systems, and Community Development, 5(4), 131-135. https://doi.org/10.5304/jafscd.2015.054.021

Meek, D., \& Tarlau, R. (2016). Critical food systems education (CFSE): Educating for food sovereignty. Agroecology and Sustainable Food Systems, 40(3), 237-260. https://doi.org/10.1080/21683565.2015.1130764

Meek, D., Bradley, K., Ferguson, B., Hoey, L., Morales, H., Rosset, P., \& Tarlau, R. (2019). Food sovereignty education across the Americas: Multiple origins, converging movements. Agriculture and Human Values, 36(3), 611-626. https://doi.org/10.1007/s10460-017-9780$\underline{1}$

Methot, S. (2019). Legacy: Trauma, story and Indigenous healing. ECW Press.

Mills, A., Durepos, G., \& Wiebe, E. (2010). Inductivism. In Encyclopedia of Case Study Research. SAGE Publications. https://doi.org/10.4135/9781412957397

Moragues-Faus, A. (2018). A critical perspective on the transformative capacity of food justice. Local Environment, 23(11), 1094-1097. https://doi.org/10.1080/13549839.2018.1532400

Morrison, D. (2011). Indigenous food sovereignty: A model for social learning. In H. Wittman, A.A. Desmarais, \& N. Wiebe (Eds.), Food sovereignty in Canada: Creating just and sustainable food systems (pp. 97-113). Fernwood. https://fernwoodpublishing.ca/book/food-sovereignty-in-canada

Myers. A.M. \& Painter, M.A. (2017). Food Insecurity in the United States of America: An examination of race/ethnicity and nativity. Food security: The science, sociology and economics of food production and access to food, 9(6),1419-1432. https://doi.org/10.1007/s12571-017-0733-8

Nierenburg, D. \& Howell, K. (2020). 24 Organizations Finding Food Justice. Food Tank. https://foodtank.com/news/2020/02/24-organizations-finding-food-justice/

Parker, B., Brady, J., Power, E., \& Belyea, S. (Eds.). (2019). Feminist food studies. Canadian Scholars' Press. 
Probyn-Rapsey, F., Donaldson, S., Ioannides, G., Lea, T., Marsh, K., Neimanis, A., Potts, A., Taylor, N., Twine, R., Wadiwel, D., \& White, S.A. (2016). A sustainable campus: The Sydney declaration on interspecies sustainability. Animal Studies Journal, 5(1), 110-151. https://ro.uow.edu.au/cgi/viewcontent.cgi?article $=1215 \&$ context=asj

Ramírez, M. M. (2015). The elusive inclusive: Black food geographies and racialized food spaces. Antipode, 47(3), 748-769. https://doi.org/10.1111/anti.12131

Reese, A., \& Garth, H. (2020). Black food matters: An introduction. In Garth H. \& Reese A. (Eds.), Black food matters: Racial justice in the wake of food justice (pp. 1-28). University of Minnesota Press. doi:10.5749/j.ctv182jtk0.3

Rowel, R., Moore, N.D., Nowrojee, S., Memiah, P., \& Bronner, Y. (2005). The utility of the environmental scan for public health practice: Lessons from an urban program to increase cancer screening. Journal of the National Medical Association, 97(4), 527-534. https://www.ncbi.nlm.nih.gov/pmc/articles/PMC2568702/

Sachs, C., \& Patel-Campillo, A. (2014). Feminist food justice: Crafting a new vision. Feminist Studies, 40(2), 396-410. http://www.jstor.org/stable/10.15767/feministstudies.40.2.396

Santone, S., Saunders, S., \& Seguin, C. (2014). Essential elements of sustainability in teacher education. Journal of Sustainability Education, 6(5), 1-15. http://www.susted.com/wordpress/content/essential-elements-of-sustainability-in-teachereducation $2014 \quad 06 /$

Sbicca, J. (2015). Food labor, economic inequality, and the imperfect politics of process in the alternative food movement. Agriculture and Human Values, 32(4), 675-687. https://doi.org/10.1007/s10460-015-9582-2

Settee, P., \& Shukla, S. (Eds.). (2020). Indigenous food systems: Concepts, cases, and conversations. Canadian Scholars' Press. https://www.canadianscholars.ca/books/indigenous-food-systems

Slocum, R. (2007). Whiteness, space and alternative food practice. Geoforum, 38(3), 520-533. https://doi.org/10.1016/j.geoforum.2006.10.006

Slocum, R., \& Cadieux, K.V. (2015). Notes on the practice of food justice in the US: understanding and confronting trauma and inequity. Journal of Political Ecology, 22(1), $27-52$.

Slocum, R., \& Saldanha, A. (Eds.). (2016). Geographies of race and food: Fields, bodies, markets. Routledge.

Slocum, R. (2018). Must everything be called "food justice?" Local Environment, 23(11), 1103 1105. https://doi.org/10.1080/13549839.2018.1532402 
Sustainable Agriculture Education Association (SAEA). (2019). Sustainable Agriculture Education Association (SAEA) Equity Statement. Equity Statement. http://www.sustainableaged.org/saea/equity-statement/

Sumner, J. (2015). Learning to eat with attitude: Critical food pedagogies. In E. Swan \& R. Flowers (Eds.), Food pedagogies (pp. 201-214). Ashgate. https://doi.org/10.4324/9781315582689-11

Sumner, J. (2016). Learning, food, and sustainability. Palgrave Macmillan. https://doi.org/10.1057/978-1-137-53904-5

Valley, W., Wittman, H., Jordan, N., Ahmed, S., \& Galt, R. (2018). An emerging signature pedagogy for sustainable food systems education. Renewable Agriculture and Food Systems, 41(5), 487-504. https://doi.org/10.1017/S1742170517000199

Valley, W., Anderson, M., Blackstone, N.T., Sterling, E., Betley, E., Akabas, S., Koch, P., Dring, C., Burke, J., \& Spiller, K. (2020). Towards an equity competency model for sustainable food systems education programs. Elementa Science of the Anthropocene, 8(33). http://doi.org/10.1525/elementa.428

Wiggins, G., \& McTighe, J. (2005). Understanding by design (2nd Ed.). Association for Supervision and Curriculum Development. http://www.ascd.org/Publications/Books/Overview/Understanding-by-Design-Expanded2nd-Edition.aspx

Wiggins, G., \& McTighe, J. (2011). Understanding by design guide to creating high quality units. Association for Supervision and Curriculum Development. http://www.ascd.org/Publications/Books/Overview/The-Understanding-by-Design-Guideto-Creating-High-Quality-Units.aspx

Williams-Forson, P., \& Wilkerson, A. (2011). Intersectionality and food studies. Food, Culture, \& Society, 14(1), 7-28. https://doi.org/10.2752/175174411X12810842291119

White, M.M. (2018). Freedom farmers: Agricultural resistance and the Black freedom movement. University of North Carolina Press.

Young, I.M. (1997). Unruly categories: A critique of Nancy Fraser's 'dual systems theory'. New Left Review 222: 147-160. 